\title{
Risk factors for poor prognosis in heart failure with particular attention to the elderly population
}

\author{
Małgorzata Dobrowolska1, Paweł Miękus', Michał Świątczak² ${ }^{\oplus}$, \\ Grzegorz Raczak² ${ }^{\circledR}$, Ludmiła Daniłowicz-Szymanowicz² $『$
}

${ }^{1}$ St.Vincent Hospital, Gdynia, Poland

${ }^{2} 2^{\text {nd }}$ Department of Cardiology and Electrotherapy, Medical University of Gdańsk, Poland

\begin{abstract}
Background: Heart failure (HF) is a leading cause of poor outcome. Age is considered one of the most critical risk factors for both the incidence and prognosis of HF. Therefore we aimed to assess the predictors of poor prognosis in $\mathrm{HF}$ patients with particular attention to the elderly population. Material and methods: We retrospectively enrolled patients hospitalized due to HF exacerbation during 2016-2017 (203 patients). The end-points were all-cause mortality and emergency rehospitalizations within a two-year follow-up period. A detailed analysis was performed in the subgroups of patients younger and older than 65 years old. Results: 121 (60\%) patients experienced the end-points. Age, low systolic blood pressure, NYHA class IV, right ventricle HF symptoms, high C-reactive protein, troponin, NT-proBNP, hyponatremia, catecholamine therapy and mechanical ventilation during hospitalization independently predicted the end-points. The elderly were characterized by a higher incidence of concomitant diseases and $\mathrm{HF}$ with moderately reduced or preserved LVEF, worse laboratory parameters and pharmacological treatment, as well as worse prognosis. Conclusion: The prognosis of patients hospitalized due to HF, mainly the elderly, is poor. Simple clinical parameters could be useful in further decision-making regarding the intensification of their treatment.
\end{abstract}

Keywords: heart failure $\cdot$ risk factors $\cdot$ prognosis $\cdot$ elderly

\section{Citation}

Dobrowolska M, Miękus P, Świątczak M, Raczak G, Daniłowicz-Szymanowicz L. Risk factors for poor prognosis in heart failure with particular attention to the elderly population. Eur J TransI Clin Med. 2021;4(2):18-30.

DOI: 10.31373/ejtcm/136327

Corresponding author:

Małgorzata Dobrowolska, St. Vincent Hospital, Gdynia, Poland

e-mail: m.d.k.dobrowolska@domax.com

Available online: www.ejtcm.gumed.edu.pl

$\underset{\substack{\text { TRANSPARENT } \\ \text { PROCESS }}}{0}$

Copyright $®$ Medical University of Gdańsk

This is Open Access article distributed under the terms of the Creative Commons Attribution-ShareAlike 4.0 International. 


\section{Introduction}

Heart failure (HF) is a continually growing global pandemic [1]. Despite significant advancements in the pharmacological and invasive treatment of HF, based on the widespread use of implantable cardioverter-defibrillators and resynchronization therapy to reduce mortality, the morbidity and mortality are still high [2-4]. HF exacerbation is the leading cause of hospital admissions [5], thus a considerable health burden for patients and the health care system [6-7]. Patients hospitalized due to $\mathrm{HF}$ exacerbation are known to have the worst prognosis $[1,4]$. Therefore, assessing such patients and identifying predictors that affect the prognosis is critical from a clinical point of view. Age is considered one of the most important risk factors for HF incidence and prognosis [8-9]. The prevalence of HF increases rapidly with age: it doubles from $6 \%$ in people aged $60-79$ years old to about $14 \%$ in those aged $\geq 80$ years old; [10] respect $4-5 \%$ of individuals 45 years and older [9]. The clinical trials to date are quite poor in the elderly population [11-13]. However, recent data from the EuroHeart Failure Survey shows that older patients with HF have poor short-term survival and are not treated according to the HF guidelines [11, 14]. Given all of the above, we aimed to assess the predictors of poor prognosis in patients hospitalized with HF with particular attention to the elderly population.

\section{Material and methods}

\section{Patients selection}

This study is a sub-analysis of our retrospective project [15] of all patients hospitalized with a diagnosis of acutely decompensated chronic HF and new-onset acute HF [16] in at a single cardiology department (St. Vincent Hospital in Gdynia, Poland) during 2016-2017. Further analysis included: the patient's biometric parameters, the medical history available in the documentation (with particular emphasis on comorbidities, condition of the coronary vessels, implanted devices, the treatment so far), physical examination findings documented during hospitalization, laboratory results, electrocardiography and echocardiography [15]. The data was obtained from the hospital's medical records and electronic patient records. Exclusion criteria were as follows: patients $<18$ years old, NYHA functional class I and II on admission, and no clinical signs of HF. All patients were followed up for two years. The composite end-point included: all-cause mortality and emergency rehospitalizations (including those due to HF exacerbation). Additional analyses were carried out differentiating between patients younger and older than 65 years of age. The study protocol was approved by the Local Ethics Committee of the Medical University of Gdańsk (decision number NKBBN/619/2018). All data we analyzed was collected during standard, routine clinical practice, therefore it was was not required to obtain the participants' written and informed consent for anonymized storage of information and its use for research.

\section{Statistical analysis}

Continuous data are presented as the median $\left(25^{\text {th }}-75^{\text {th }}\right.$ percentiles), whereas categorical variables as numbers ( $\mathrm{n}$ ) and percentages (\%). Comparisons between the patients were made with $U$ Mann-Whitney's test or the Fisher's exact test due to abnormally distributed variables. An association between the analyzed parameters and the end-point was assessed using the univariate and multivariate Cox hazard models. The accuracy of pre-specified cut-off values for the analyzed parameters and their association as potential predictors of the study end-point was determined by area under (AUC) the receiver-operating characteristic (ROC) curve. All the results were considered statistically significant with $\mathrm{p} \leq 0.05$. The statistical analysis was performed using the Statistica 12.0 software (StatSoft, Tulsa OK, USA) and R 2.15.2 (R Project).

\section{Results}

We included 203 patients hospitalized due to HF exacerbation in the years 2016-2017. Within a two-year observation period, 121 instances of composite end-points (all-cause mortality and emergency rehospitalizations) were documented.

\section{Clinical, laboratory, and echocardiographic findings}

Most of the patients included in the study were men ( $\mathrm{Ta}$ ble 1). Patients who experienced end-points were older (median age 73 versus 68 years old in group without endpoints, $p=0.046)$, they more frequently had a history of atrial fibrillation/flutter ( $44 \%$ vs. $18 \%, p<0.001)$ and diabetes ( $29 \%$ vs. $13 \%, p=0.010)$, were also more likely to undergo coronary revascularization ( $47 \%$ vs. $30 \%, p=0.020$ ) and had lower systolic blood pressure (SBP) at discharge (median 120 vs. 128 $\mathrm{mmHg}, \mathrm{p}=0.047$ ). In addition they had worse renal function indices, lower sodium values, higher troponin and natriuretic peptide levels (Table 1). In the echocardiographic assessment, these patients were characterized by more advanced left ventricular diastolic dysfunction and a trend towards worse systolic function (Table 1). There were no differences in pharmacotherapy; moreover, it should be emphasized that the majority of patients were treated according to the current guidelines [8]: $>90 \%$ of patients received a beta-blocker, $>80 \%$ were treated with an ACE-inhibitor or sartans; however the frequency of spironolactone/eplerenone use was lower than suggested in the guidelines (Table 1). 
Table 1. Baseline clinical characteristics of the study patients according the end-point

\begin{tabular}{|c|c|c|c|}
\hline Parameters & $\begin{array}{l}\text { End-point (-) } \\
\qquad n=82\end{array}$ & $\begin{array}{l}\text { End-point (+) } \\
\qquad n=121\end{array}$ & $\mathbf{p}$ \\
\hline Male, n (\%) & $56(68)$ & $88(73)$ & 0.531 \\
\hline Age (years) & $68(61-79)$ & $73(64-81)$ & 0.046 \\
\hline \multicolumn{4}{|c|}{ Medical history } \\
\hline Coronary artery disease, n (\%) & $45(56)$ & $81(68)$ & 0.135 \\
\hline Revascularization (PCI/CABG), n (\%) & $25(30)$ & $57(47)$ & 0.020 \\
\hline ICD (including CRT-D) & $14(17)$ & $30(25)$ & 0.212 \\
\hline Atrial fibrillation/flutter, n (\%) & $15(18)$ & $53(44)$ & $<0.001$ \\
\hline Hypertension, n (\%) & $28(34)$ & $47(39)$ & 0.554 \\
\hline Diabetes mellitus, n (\%) & $11(13)$ & $35(29)$ & 0.010 \\
\hline Cancer, n (\%) & $2(5)$ & $11(26)$ & 0,016 \\
\hline \multicolumn{4}{|c|}{ Cause of hospitalization } \\
\hline Infections, $\mathrm{n}(\%)$ & $24(29)$ & $50(41)$ & 0.102 \\
\hline Acute coronary syndrome, n (\%) & $2(2)$ & $6(5)$ & 0.478 \\
\hline Tachyarrythmias, n (\%) & $20(24)$ & $30(25)$ & 1.000 \\
\hline Unknown reason, $\mathrm{n}(\%)$ & $38(46)$ & $40(33)$ & 0.077 \\
\hline Other, n (\%) & $9(11)$ & $12(10)$ & 0.818 \\
\hline The length of hospitalisation (days) & $7(5-9)$ & $8(5-12)$ & 0.041 \\
\hline \multicolumn{4}{|c|}{ Clinical and diagnostic parameters } \\
\hline Resting heart rate (beats /min) & $83(75-110)$ & $90(75-110)$ & 0,225 \\
\hline $\mathrm{SBP}(\mathrm{mmHg})$ & $128(115-133)$ & $120(109-131)$ & 0.047 \\
\hline NYHA class IV at admission, n (\%) & $27(33)$ & $55(46)$ & 0.080 \\
\hline $\begin{array}{l}\text { Right ventricle HF symptoms } \\
\text { at admission, } \mathrm{n}(\%)\end{array}$ & $20(24)$ & $52(43)$ & 0.007 \\
\hline Hemoglobin (g/dl) & $14(12-15)$ & $13(12-15)$ & 0.186 \\
\hline C-reactive protein (mg/l) & $7(3-16)$ & $8(4-22)$ & 0.105 \\
\hline
\end{tabular}




\begin{tabular}{|c|c|c|c|}
\hline Sodium (mmol/l) & $141(139-142)$ & $140(137-142)$ & 0.030 \\
\hline Glucose (mg/dl) & $110(98-141)$ & $123(105-163)$ & 0.071 \\
\hline High-sensitivity troponin $\mathrm{T}(\mathrm{ng} / \mathrm{ml})$ & $\begin{array}{c}0.042 \\
(0.017-0.043)\end{array}$ & $\begin{array}{c}0.105 \\
(0.021-0.076)\end{array}$ & $<0.001$ \\
\hline Creatinine (mg/dl) & $1.24(0.81-1.32)$ & $1.25(0.91-1.51)$ & 0.072 \\
\hline NT-proBNP (ng/l) & $\begin{array}{c}2432 \\
(732-6115)\end{array}$ & $\begin{array}{c}5170 \\
(2474-10449)\end{array}$ & $<0.001$ \\
\hline \multicolumn{4}{|c|}{ Echocardiographic parameters } \\
\hline LVEF (\%) & $37(25-50)$ & $33(23-45)$ & 0.061 \\
\hline LVEF $<40, \mathrm{n}(\%)$ & $44(54)$ & $79(66)$ & \multirow{3}{*}{0.202} \\
\hline LVEF 40-49, n (\%) & $16(20)$ & $19(16)$ & \\
\hline LVEF $\geq 50, n(\%)$ & $22(27)$ & $22(18)$ & \\
\hline Diastolic dysfunction $2 / 3^{\circ}, \mathrm{n}(\%)$ & $39(64)$ & $72(82)$ & 0.032 \\
\hline Left atrium diameter $(\mathrm{cm})$ & $4.84(4.4-5.3)$ & $5.04(4.6-5.4)$ & 0.085 \\
\hline $\begin{array}{l}\text { Right ventricular systolic pressure } \\
\text { increased, } \mathrm{n}(\%)\end{array}$ & $64(82)$ & $115(97)$ & $<0.001$ \\
\hline \multicolumn{4}{|c|}{ In-hospital treatment } \\
\hline Catecholamine, n (\%) & $1(1)$ & $8(7)$ & 0.087 \\
\hline Mechanical ventilation, $\mathrm{n}$ (\%) & $3(4)$ & $9(7)$ & 0.367 \\
\hline \multicolumn{4}{|c|}{ Treatment at discharge } \\
\hline ACE-inhibitor/ Sartans, n (\%) & $73(89)$ & $95(81)$ & 0.166 \\
\hline Spironolactone / Eplerenone, n (\%) & $43(52)$ & $54(48)$ & 0.663 \\
\hline Beta-adrenolytics, n (\%) & $76(93)$ & $102(91)$ & 0.795 \\
\hline Statins, n (\%) & $50(61)$ & $80(71)$ & 0.164 \\
\hline Diuretics, n (\%) & $75(91)$ & $108(96)$ & 0.208 \\
\hline Potassium, n (\%) & $56(68)$ & $81(72)$ & 0.633 \\
\hline Antiplatelet therapy, n (\%) & $20(24)$ & $39(35)$ & 0.155 \\
\hline NOAC, VKA, LMWH, n (\%) & $58(71)$ & $79(71)$ & 1.000 \\
\hline
\end{tabular}




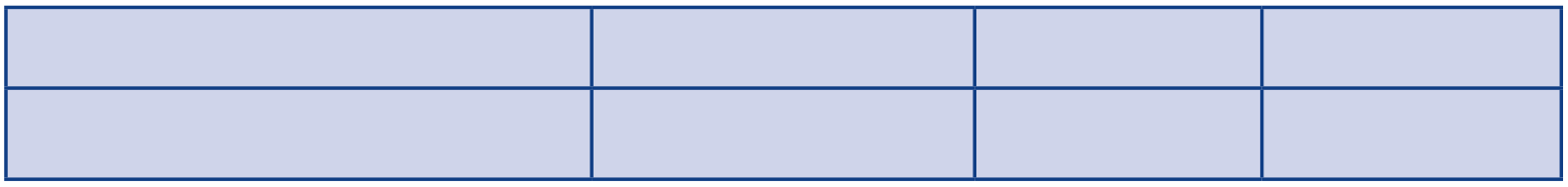

Categorical variables are presented as number and percentage. Continuous variables are presented as median and interquartile range. $P$ values of $<0.05$ are considered significant.

ACE-inhibitor - angiotensin converting enzyme inhibitor; CABG - coronary artery bypass grafting; CRT-D - cardiac resynchronization therapy defibrillator; ICD - implantable cardioverter-defibrillator; LMWH - low molecular weight heparin; LVEF- left ventricular ejection fraction; NOAC - novel oral anticoagulants; NT - proBNP-N-terminal pro brain natriuretic peptide; NYHA - New York Heart Association; $\mathrm{PCl}$ - percutaneous coronary intervention; SBP - systolic blood pressure; VKA - vitamin K antagonists.

Conversion factors to SI units are as follows: for creatinine $\mathrm{mg} / \mathrm{dl} \rightarrow \mathrm{umol} / \mathrm{L}: 0.6206$; for CRP $\mathrm{mg} / \mathrm{l} \rightarrow \mathrm{nmol} / \mathrm{L}, 9.524 ;$ for glucose $\mathrm{mg} / \mathrm{dl} \rightarrow$ $\mathrm{mmol} / \mathrm{L}, 0.05551$, for hemoglobin $\mathrm{g} / \mathrm{dl} \rightarrow \mathrm{mmol} / \mathrm{L}, 88.42$; for high-sensitivity troponin $\mathrm{T} \mathrm{ng} / \mathrm{ml} \rightarrow \mu \mathrm{g} / \mathrm{L}, 1,0 ;$ for NT-proBNP ng/l $\rightarrow$ pmol/L, 0.118

\section{The predictors of the end-points}

Table 2 presents the pre-specified on ROC curve analysis cut-off values for continuous variables with the highest discriminatory power in predicting the end-points (Table 2 ). In the Cox proportional hazard regression analysis, we revealed statistically significant clinical and laboratory variables, which predicted the end-points: age $\geq 73$ years old, lower SBP ( $\leq 120 \mathrm{mmHg}$ ), NYHA class IV on admission, right-sided HF symptoms, C-reactive protein $\geq 31.4(\mathrm{mg} / \mathrm{l})$, sodium $\leq$ $137 \mathrm{mmol} / \mathrm{l}$, troponin level $\geq 0.044 \mathrm{ng} / \mathrm{ml}$, NT-proBNP level $\geq 2453 \mathrm{ng} / \mathrm{l}$, catecholamine use and mechanical ventilation during hospitalization (Table 3).

Table 2. Prognostic accuracy of the pre-specified cut-off values for analyzed parameters as predictors of composite end-points during the follow-up

\begin{tabular}{|c|c|c|c|c|c|}
\hline \multirow{2}{*}{ Parameters } & \multirow{2}{*}{ AUC } & \multicolumn{2}{|c|}{$\begin{array}{c}\text { Characteristics } \\
(95 \% \mathrm{CI})\end{array}$} & \multicolumn{2}{|c|}{$\begin{array}{l}\text { Predictive Value } \\
\text { ( } 95 \% \mathrm{CI})\end{array}$} \\
\hline & & Sensivity (\%) & Specificity (\%) & Positive (\%) & Negative (\%) \\
\hline Age $\geq 73$ years old & 0.62 & 66 & 52 & 48 & 69 \\
\hline $\mathrm{SBP} \leq 120 \mathrm{mmHg}$ & 0.58 & 70 & 50 & 47 & 73 \\
\hline $\begin{array}{l}\text { C-reactive protein } \\
\quad \geq 31.4 \mathrm{mg} / \mathrm{l}\end{array}$ & 0.56 & 93 & 21 & 42 & 83 \\
\hline Sodium $\leq 137 \mathrm{mmol} / \mathrm{l}$ & 0.59 & 95 & 23 & 45 & 87 \\
\hline $\begin{array}{l}\text { High-sensitivity troponin } \\
\qquad \mathrm{T} \geq 0.044 \mathrm{ng} / \mathrm{ml}\end{array}$ & 0.64 & 79 & 45 & 49 & 76 \\
\hline Creatinine $\geq 1.15 \mathrm{mg} / \mathrm{dl}$ & 0.58 & 70 & 44 & 46 & 68 \\
\hline NT-proBNP $\geq 2453$ ng/l & 0.67 & 51 & 75 & 58 & 69 \\
\hline
\end{tabular}


Table 3. Univariate and multivariate Cox proportional hazard regression as a predictor of composite end-point )

\begin{tabular}{|c|c|c|c|c|}
\hline \multirow[b]{2}{*}{ Parameters } & \multicolumn{2}{|c|}{ Univariate analysis } & \multicolumn{2}{|c|}{ Multivariate analysis } \\
\hline & HR (95\% CI) & $\mathbf{p}$ & HR ( $(95 \%$ CI) & $\mathbf{p}$ \\
\hline Age $\geq 73$ years & $1.49(1.04-2.13)$ & 0.028 & $1.89(1.24-2.88)$ & 0.003 \\
\hline Atrial fibrillation / flutter & $1.65(1.15-2.37)$ & 0.007 & - & - \\
\hline Cancer & $2.48(1.24-4.96)$ & 0.010 & - & - \\
\hline $\mathrm{SBP} \leq 120 \mathrm{mmHg}$ & $1.52(1.01-2.29)$ & 0.044 & $1.65(1.09-2.49)$ & 0.018 \\
\hline NYHA class IV at admission & $1.51(1.05-2.17)$ & 0.024 & $1.55(1.06-2.25)$ & 0.023 \\
\hline Right ventricle HF symptoms & $1.62(1.13-2.32)$ & 0.009 & $2.72(1.15-6.40)$ & 0.019 \\
\hline C-reactive protein $\geq 31.4 \mathrm{mg} / \mathrm{l}$ & $1.97(1.25-3.10)$ & 0.004 & $2.75(1.16-6.53)$ & 0.022 \\
\hline Sodium $\leq 137 \mathrm{mmol} / \mathrm{l}$ & $1.97(1.27-3.06)$ & 0.003 & $3.42(1.32-8.87)$ & 0.011 \\
\hline $\begin{array}{l}\text { High-sensitivity troponin } \mathrm{T} \\
\quad \geq 0.044 \mathrm{ng} / \mathrm{ml}\end{array}$ & $2.0(1.39-2.90)$ & $<0.001$ & $1.67(1.12-2.50)$ & 0.012 \\
\hline Creatinine $\geq 1.15 \mathrm{mg} / \mathrm{dl}$ & $1.47(1.03-2.12)$ & 0.039 & - & - \\
\hline NT-proBNP $\geq 2453$ ng/l & $2.25(1.47-3.45)$ & $<0.001$ & $3.21(1.12-5.87)$ & 0.004 \\
\hline Infection at hospitalization & $2.74(1.59-4.73)$ & $<0.001$ & - & - \\
\hline Amine therapy & $3.17(1.54-6.50)$ & 0.002 & $1.59(1.10-2.29)$ & 0.014 \\
\hline $\begin{array}{l}\text { Mechanical ventilation } \\
\text { during hospitalization }\end{array}$ & $2.19(1.11-4.31)$ & 0.024 & $3.85(1.35-11.03)$ & 0.012 \\
\hline
\end{tabular}

Abbreviations: HR - hazard ratio; other: see Table 1

\section{Clinical characteristics and prognosis depending on age}

Patients aged $\geq 65$ years more frequently had a history of coronary artery disease (CAD) $(72 \%$ vs. $45 \%, p<0.001)$, and higher rate of revascularization ( $47 \%$ vs. $26 \%, p=0.004$ ); similarly, older patients more frequently had history of atrial fibrillation/flutter ( $39 \%$ vs. $24 \%, p=0.040$ ). Older patients who required longer hospitalization (median 8 vs. 7 days, $p$ $=0.035$ ) were characterized by lower hemoglobin and higher creatinine values and statistically significantly higher tro- ponin levels (Table 4). It should be noted that the elderly group had a higher left ventricular ejection fraction (LVEF) and $\mathrm{HF}$ with LVEF $>40 \%$ was reported significantly more often (Table 4). Regarding the pharmacological treatment, the subgroup $\geq 65$ years old was significantly less often treated with aldosterone antagonists (spironolactone and eplerenone) and more often with statins. Composite end-points were significantly more frequent in the elderly subgroup in comparison to younger: $65 \%$ vs $49 \%(p=0.024)$, including a trend towards higher all-cause mortality (38\% and $24 \%$ respectively, $p=0.057$ ). 
Table 4. Baseline clinical characteristics of the study patients in comparison between $<65$ and $\geq 65$-year old patients

\begin{tabular}{|c|c|c|c|}
\hline Parameters & $\begin{array}{c}\text { Age }<65 \\
n=68\end{array}$ & $\begin{array}{c}\text { Age } \geq 65 \\
n=135\end{array}$ & p \\
\hline Male, n (\%) & $55(81)$ & $89(66)$ & 0.033 \\
\hline \multicolumn{4}{|c|}{ Medical history } \\
\hline Coronary artery disease, n (\%) & $30(45)$ & $96(72)$ & $<0.001$ \\
\hline Revascularization (PCI/CABG), n (\%) & $18(26)$ & $64(47)$ & 0.004 \\
\hline ICD (including CRT-D) & $13(19)$ & $19(14)$ & 0.320 \\
\hline Atrial fibrillation/flutter, n (\%) & $16(24)$ & $52(39)$ & 0.040 \\
\hline Hypertension, n (\%) & $22(32)$ & $53(39)$ & 0.359 \\
\hline Diabetes mellitus, n (\%) & $13(19)$ & $33(24)$ & 0.478 \\
\hline Cancer, n (\%) & 2(9) & $11(19)$ & 0.331 \\
\hline \multicolumn{4}{|c|}{ Cause of hospitalization } \\
\hline Infections, n (\%) & $23(34)$ & $51(38)$ & 0.644 \\
\hline Acute coronary syndrome, n (\%) & $1(1)$ & $7(5)$ & 0.272 \\
\hline Tachyarrythmias, n (\%) & $15(22)$ & $35(26)$ & 0.607 \\
\hline Unknown reason, $\mathrm{n}(\%)$ & $34(50)$ & $44(33)$ & 0.022 \\
\hline Other, n (\%) & $3(4)$ & $18(13)$ & 0.053 \\
\hline The length of hospitalisation (days) & $7(4-9)$ & $8(5-12)$ & 0.035 \\
\hline \multicolumn{4}{|c|}{ Clinical and diagnostic parameters } \\
\hline Resting heart rate (beats /min) & $90(75-115)$ & $83(70-110)$ & 0.136 \\
\hline $\mathrm{SBP}(\mathrm{mmHg})$ & $115(106-130)$ & $124(115-135)$ & 0.007 \\
\hline NYHA class IV at admission, n (\%) & $32(47)$ & $50(37)$ & 0.225 \\
\hline $\begin{array}{l}\text { Right ventricle HF symptoms } \\
\text { at admission, } \mathrm{n}(\%)\end{array}$ & $20(29)$ & $52(39)$ & 0.217 \\
\hline Hemoglobin ( $\mathrm{g} / \mathrm{dl}$ ) & $14.2(12.4-15.6)$ & $13.4(11.7-14.7)$ & 0.041 \\
\hline C-reactive protein $(\mathrm{mg} / \mathrm{l})$ & $7.9(4.7-15.7)$ & $6.9(3.4-20.3)$ & 0.360 \\
\hline Sodium (mmol/l) & $140(138-141)$ & $140(138-142)$ & 0.076 \\
\hline
\end{tabular}




\begin{tabular}{|c|c|c|c|}
\hline Glucose (mg/dl) & $113(98-143)$ & $120(102-154)$ & 0.221 \\
\hline High-sensitivity troponin $\mathrm{T}(\mathrm{ng} / \mathrm{ml})$ & $0.028(0.018-0.05)$ & $\begin{array}{c}0.034 \\
(0.019-0.069)\end{array}$ & 0.064 \\
\hline Creatinine $(\mathrm{mg} / \mathrm{dl})$ & $0.95(0.8-1.3)$ & $1.1(0.9-1.5)$ & 0.005 \\
\hline NT-proBNP (ng/l) & $3418(863-7384)$ & $4416(1809-8557)$ & 0.027 \\
\hline \multicolumn{4}{|c|}{ Echocardiographic parameters } \\
\hline LVEF (\%) & $30(20-39)$ & $38(27-50)$ & 0.002 \\
\hline LVEF < 40, n (\%) & $51(75)$ & $72(54)$ & \multirow{3}{*}{0.013} \\
\hline LVEF 40-49, n (\%) & $8(12)$ & $27(20)$ & \\
\hline LVEF $\geq 50, \mathrm{n}(\%)$ & $9(13)$ & $35(26)$ & \\
\hline Diastolic dysfunction $2 / 3^{\circ}, \mathrm{n}(\%)$ & $40(80)$ & $71(72)$ & 0.274 \\
\hline Left atrium diameter $(\mathrm{cm})$ & $5(4.5-5.3)$ & $4.9(4.5-5.3)$ & 0.166 \\
\hline $\begin{array}{l}\text { Right ventricular systolic pressure } \\
\text { increased, } \mathrm{n}(\%)\end{array}$ & $59(91)$ & $120(91)$ & 1.000 \\
\hline \multicolumn{4}{|c|}{ In-hospital treatment } \\
\hline Amine, n (\%) & $6(9)$ & $3(2)$ & 0.063 \\
\hline Mechanical ventilation, n (\%) & $7(10)$ & $4(3)$ & 0.045 \\
\hline \multicolumn{4}{|c|}{ Treatment at discharge } \\
\hline ACE-inhibitor/ Sartans, n (\%) & $55(83)$ & $113(85)$ & 0.836 \\
\hline Spironolactone /Eplerenone, n (\%) & $41(63)$ & $56(43)$ & 0.015 \\
\hline Beta-adrenolytics, n (\%) & $59(91)$ & $119(92)$ & 0.784 \\
\hline Statins, n (\%) & $36(55)$ & $94(73)$ & 0.016 \\
\hline Diuretics, n (\%) & $62(95)$ & $121(94)$ & 0.754 \\
\hline Potassium, n (\%) & $41(63)$ & $96(74)$ & 0.132 \\
\hline Antiplatelet therapy, n (\%) & $18(28)$ & $41(32)$ & 0.622 \\
\hline NOAC, VKA, LMWH, n (\%) & $41(63)$ & $96(74)$ & 0.132 \\
\hline Digoxin, n (\%) & $11(17)$ & $18(14)$ & 0.670 \\
\hline Amiodarone, n (\%) & $8(12)$ & $15(12)$ & 1.000 \\
\hline
\end{tabular}




\section{Discussion}

Our single-center retrospective study analyzed risk factors for poor prognosis in $\mathrm{HF}$ with particular attention to the elderly population. Over the years, many important risk factors for worsened HF prognosis have been reported, including clinical, laboratory and echocardiographic parameters [17-19]. Among the well-known clinical parameters: age, male sex, high NYHA class, low SBP, arrhythmias with rapid ventricular rate, infections, and the presence of comorbidities (e.g. ischemic heart disease, diabetes, renal failure, pulmonary disease, cancer) are the essential risk factors of poor prognosis [20-23]. The results of our study are congruent with this data: age $\geq 73$ years old, SBP at discharge $\leq$ $120 \mathrm{mmHg}$, NYHA class IV at admission, symptoms of right ventricle HF, infection as the cause of initial hospitalization and concomitant diseases (cancer or atrial fibrillation/flutter) were significant predictors of composite end-points (all-cause mortality and rehospitalizations due to emergency reasons) in the two-year follow-up period. The hos pitalization time was significantly longer for patients with the end-points in the observation period (Table 1), which is in agreement with the previous data from the literature [6]. Mechanical ventilation or catecholamine therapy, which according to our data was used more frequently in patients with the end-points, became significant risk factors for poor prognosis in both univariate and multivariate Cox analysis. Among the laboratory parameters, the most robust predictors according to the literature are renal function, hyponatremia, increased troponins, and low hemoglobin [18-19, 24-25]. Our results confirm this data (Table 3 ).

\section{The specific characteristics of the elderly population}

It is well-known that elderly patients often present with complex comorbidities (hypertension, CAD, atrial fibrillation, peripheral vascular disease, kidney failure, or anemia) compared to the younger population [5, 26]. We confirmed this observation in our study (Table 4). Epidemiological data shows that CAD is the dominant comorbidity and the HF's main etiological unit [7]. In the presented project, almost 3 out of 4 patients from the elderly subgroup had CAD diagnosis. Additionally, these patients underwent revascularization more frequently, which is in agreement with the general trend observed in cardiology: the elderly may benefit more from invasive treatment, despite a higher periprocedural risk [27-28]. The general percentage of revascularized patients is surprisingly low in the study group with the diagnosis of CAD, although not every CAD patient requires invasive treatment. What is more, that could reflect the real condition of invasive treatment in a district hospital. The second most common comorbidity associated with HF, especially in the elderly, is atrial fibrillation. Data from the literature and large registries (EORP-AF, Framingham Heart Study [29-30]) confirm the increased rate of this arrhythmia with the aging of the population and the occurrence of HF exacerbations in the elderly [29, 31-32]. We also observed this correlation in our study: the number of patients with a history of atrial fibrillation was almost twice as high in the subgroup $\geq 65$ years old, compared to subgroup < 65 years old: $39 \%$ vs. $24 \%(p=0.040)$. According to the literature, arterial hypertension is another comorbidity increasing the number of hospitalizations in the elderly $[17,20]$ and although in our study these differences were not statistically significant, its incidence was higher (Table 4).

In the senior population laboratory tests typically show deterioration of kidney function and anemia [20, 24], both of which were noted in our study (Table 4). Particular attention should be paid to the role of the assessment of natriuretic peptides in older patients hospitalized due to exacerbation of HF. It is known that NT-proBNP predicts mortality among the older and very elderly patients with chronic HF [33]. In the elderly population with HF, the higher cut-off value for NT-proBNP should be considered. In our study, it was $2453 \mathrm{ng} / \mathrm{l}$ for the composite end-points prediction (Table 2), while in the study by Vergaro et al. for the prognosis of the annual death of people aged $\geq 77$ years old, it was as high as $4188 \mathrm{ng} /$ I [34].

During the last twenty years, it was established that a significant percentage of patients with $\mathrm{HF}$, especially the elderly, have preserved left ventricular systolic function $[5,21,26$, 35]. The latest HF guidelines published by the European Society of Cardiology [8] distinguish HF with LVEF that is significantly reduced (<40\%), moderately reduced (LVEF $40-49 \%$ ) and preserved $(\geq 50 \%)$. A fascinating result of the presented study is a statistically significant higher incidence of patients with LVEF of $\geq 40 \%$ in the subgroup of older adults. Moreover, the median LVEF value in these patients was also higher (Table 4). It is of note that the diameters of the left atrium did not differ statistically between the groups, which could explain that the enlargement of the left atrium is not only consequence of the diastolic but systolic dysfunction as well.

\section{Comparison of post-hospital recommendations according to the age}

Data from the literature shows that older patients with $\mathrm{HF}$ are characterized by worse pharmacotherapy compared to younger patients [36]. This may be explained by numerous comorbidities and complications resulting from the use of certain groups of drugs or insufficient compliance [37]. The results of our single-center study present a therapy that can be considered optimal in comparison to the current guidelines $[8,38]$, because the percentage of people $\geq 65$ years of age who use beta-blockers, ACE inhibitors/sartans remains high, which is consistent with the data from the Polish arm of the Heart Failure Pilot Survey 
conducted in 26 Polish cardiological centers [12]. The exception is the percentage of patients using mineralocorticoid antagonists, which in the for the subgroup $\geq 65$ years of age is $43 \%$. This group is half the size of the subgroup of patients $<65$ years of age who were taking mineralocorticoid antagonists. It can be associated with a more frequent occurrence of comorbidities, including chronic renal disease which can be exacerbated by these medications. This trend of lower adherence to current guidelines in the geriatric population, resulting from poorer renal function, is also confirmed by data from the literature $[28,37]$. There are encouraging reports of a slight improvement in prognosis in this challenging group of patients taking spironolactone at GFR $>30 \mathrm{ml} /$ $\min / 1.73 \mathrm{~m} 2$ [39], which may be an essential therapeutic direction in the future. Our results indicate an interesting trend towards greater use of anticoagulant and antiplatelet therapy in the elderly (Table 4), which is most likely due to both a higher proportion of CAD and atrial fibrillation in this subgroup. The above data is in agreement with the results from the European registers [29].

It should be noted that the percentage of patients enrolled in the study with implantable cardioverter-defibrillators (including cardiac resynchronization therapy) is disproportionately small concerning the number of patients with LVEF $<40 \%$ and even lower in the elderly patients (Table 4). We precisely analyzed and discussed this problem in our previous study [15]. It also seems interesting that the subgroup with the composite end-points, was characterized by a higher rate of implanted ICD/CRT. This situation can be explained by the fact, that patients with implanted ICD and CRT devices usually have a worse prognosis. In addition, these devices protect mainly against life-threatening arrhythmic events and not against the other causes of cardiac death.

\section{The prognosis of HF patients according to age}

The latest data from the literature suggests that the overall mortality in the senior population is decreasing: the age-standardized death rate has decreased by $40 \%$, and the mean age of death due to HF has increased from 80.0 to 82.7 years in seven European countries during the last two decades [37]. The survival of HF patients is low, amounting to $17 \%$ in the first year after diagnosis and approximately $40-50 \%$ in 5 years, which is a worse result than in the case of many cancers [14]. Data from the literature on patients with HF in the geriatric population shows that their mortality is slightly over $20 \%$ within one year of diagnosis [12, 37], increasing to $36.7 \%$ after two years [37]. In our study, the 2-year mortality in patients $\geq 65$ years old was similar and amounted to $38 \%$, which confirms the above-mentioned European trend of improving mortality in the geriatric population. However, this percentage is still higher than in the younger population.
As we mentioned in the introduction, hospitalizations due to HF exacerbation are the leading cause of hospital admissions, particularly in patients $>65$ years old [5]. According to the ESC-HF Pilot registries, the general population's rehospitalization rates within one year amounted to $43.9 \%$ [14]. Korean studies conducted in patients $>65$ years hospitalized for $\mathrm{HF}$ within 30 days showed a $34.6 \%$ rehospitalization rate [40]. Even more alarming results are reported by Tuppin et al. [22], who collected information from the national health insurance information system about hospitalizations in France in 2009, where the 2-year all-cause readmission rate was $69 \%$. In our 2 -year observation, as many as $65 \%$ of seniors experienced death or rehospitalization due to emergency cases, which was significantly greater than in the younger subgroup. That results seem to confirm that more extensive studies based on the elderly population are needed.

\section{Study limitations}

Our study has several limitations. First of all, it was a single-center, retrospective analysis and our results should thus be interpreted with caution. The study group is small and included only patients with HF exacerbation as the main diagnosis. In addition, some clinical data was not available in the documentation (e.g. the assessment of hypercholesterolemia, the width of the QRS complex, pre-admission drugs, smoking), hence the statistical evaluation of our data may raise some doubts.

\section{Conclusions}

Simple clinical parameters (e.g. age, systolic blood pressure, NYHA class IV, right ventricle HF symptoms, increased natriuretic peptide, C-reactive protein, troponin, hyponatre$\mathrm{mia}$ ) as well as catecholamine therapy and mechanical ventilation during hospitalization due to HF exacerbation, are the substantial, independent risk factors for poor prognosis. The elderly patients are characterized by more comorbidities, worse laboratory results, higher HF frequency with moderately reduced LVEF and worse prognosis. Our pilot study could help in decision-making on the intensification of outpatient and inpatient treatment to increase its effectiveness. In turn, this could translate into a reduction of the frequent end-point events, a reduction in the frequency of hospitalizations, improved prognosis and measurable economic benefits.

\section{Acknowledgments}

None. 


\section{References}

1. Ambrosy AP, Fonarow GC, Butler J, Chioncel O, Greene SJ, Vaduganathan M, et al. The Global Health and Economic Burden of Hospitalizations for Heart Failure. J Am Coll Cardiol [Internet]. 2014 Apr;63(12):1123-33. Available from: https:// linkinghub.elsevier.com/retrieve/pii/S0735109714002915

2. Mozaffarian D, Benjamin EJ, Go AS, Arnett DK, Blaha MJ, Cushman M, et al. Executive Summary: Heart Disease and Stroke Statistics-2016 Update. Circulation [Internet]. 2016 Jan 26;133(4):447-54. Available from: https://www.ahajournals. org/doi/10.1161/CIR.0000000000000366

3. Savarese G, Lund LH. Global Public Health Burden of Heart Failure. Card Fail Rev [Internet]. 2017;03(01):7-11. Available from: https://www.cfrjournal.com/articles/global-public-health-burden-heart-failure

4. Shah KS, Xu H, Matsouaka RA, Bhatt DL, Heidenreich PA, Hernandez AF, et al. Heart Failure With Preserved, Borderline, and Reduced Ejection Fraction. J Am Coll Cardiol [Internet]. 2017 Nov 14;70(20):2476-86. Available from: https://doi. org/10.1016/i.jacc.2017.08.074

5. Cvetinovic N, Loncar G, Farkas J. Heart failure management in the elderly - a public health challenge. Wien Klin Wochenschr [Internet]. 2016 Dec 29;128(S7):466-73. Available from: http://link.springer.com/10.1007/s00508-016-1138-y

6. Zaprutko J, Michalak M, Nowicka A, Dankowski R, Drożdż J, Ponikowski P, et al. Hospitalisation length and prognosis in heart failure patients. Kardiol Pol [Internet]. 2017 Apr 14;75(4):323-31. Available from: https://journals.viamedica.pl/ kardiologia polska/article/view/78438

7. Dharmarajan K, Rich MW. Epidemiology, Pathophysiology, and Prognosis of Heart Failure in Older Adults. Heart Fail Clin [Internet]. 2017 Jul;13(3):417-26. Available from: https://linkinghub.elsevier.com/retrieve/pii/S1551713617300144

8. Ponikowski P, Voors AA, Anker SD, Bueno H, Cleland JGF, Coats AJS, et al. 2016 ESC Guidelines for the diagnosis and treatment of acute and chronic heart failure. Eur Heart J [Internet]. 2016 Jul 14;37(27):2129-200. Available from: https:// academic.oup.com/eurheartj/article-lookup/doi/10.1093/eurheartj/ehw128

9. Fagotto V, Cavarape A, Boccanelli A. Heart failure in the elderly: A geriatric syndrome. Picture of the modern situation. Monaldi Arch Chest Dis [Internet]. 2019 Apr 12;89(1). Available from: https://www.monaldi-archives.org/index.php/ macd/article/view/monaldi.2019.1031

10. Gorodeski EZ, Goyal P, Hummel SL, Krishnaswami A, Goodlin SJ, Hart LL, et al. Domain Management Approach to Heart Failure in the Geriatric Patient. J Am Coll Cardiol [Internet]. 2018 May;71(17):1921-36. Available from: https://linkinghub.elsevier.com/retrieve/pii/S0735109718335307

11. Mahjoub H, Rusinaru D, Soulière V, Durier C, Peltier M, Tribouilloy C. Long-term survival in patients older than 80 years hospitalised for heart failure. A 5-year prospective study. Eur J Heart Fail [Internet]. 2008 Jan;10(1):78-84. Available from: http://doi.wiley.com/10.1016/i.ejheart.2007.11.004

12. Poliwczak A, Śmigielski J, Bała A, Straburzyńska-Migaj E, Tymińska A, Balsam P, et al. Treatment of heart failure in the elderly in Poland. The results of the Polish part of EURObservational Research Programme: The Heart Failure Pilot Survey. Adv Clin Exp Med [Internet]. 2019 May 6;28(10):1351-8. Available from: http://www.advances.umed.wroc.pl/en/ article/2019/28/10/1351/

13. Flather MD, Shibata MC, Coats AJS, Van Veldhuisen DJ, Parkhomenko A, Borbola J, et al. Randomized trial to determine the effect of nebivolol on mortality and cardiovascular hospital admission in elderly patients with heart failure (SENIORS). Eur Heart J [Internet]. 2005 Feb 1;26(3):215-25. Available from: http://academic.oup.com/eurheartj/article/26/3/215/2888055/Randomized-trial-to-determine-the-effect-of

14. Maggioni AP, Dahlström U, Filippatos G, Chioncel O, Leiro MC, Drozdz J, et al. EUR Observational Research Programme: regional differences and 1-year follow-up results of the Heart Failure Pilot Survey (ESC-HF Pilot). Eur J Heart Fail [Internet]. 2013 Jul;15(7):808-17. Available from: http://doi.wiley.com/10.1093/eurjhf/hfq154

15. Dobrowolska M, Miękus P, Świątczak M, Raczak G, Daniłowicz-Szymanowicz L. Two-year prognosis of patients hospitalized for decompensated heart failure in a district general hospital. Kardiol Pol [Internet]. 2021 Mar 25;79(3):302-10. Available from: https://journals.viamedica.pl/kardiologia polska/article/view/82818

16. Hummel A, Empen K, Dörr M, Felix SB. De Novo Acute Heart Failure and Acutely Decompensated Chronic Heart Failure. Dtsch Aerzteblatt Online [Internet]. 2015 Apr 24;112:298-310. Available from: https://www.aerzteblatt.de/10.3238/ arztebl.2015.0298

17. Salamanca-Bautista P, Conde-Martel A, Aramburu-Bodas Ó, Formiga F, Trullàs JC, Quesada-Simón MA, et al. Precipitating factors of heart failure admission: Differences related to age and left ventricular ejection fraction. Int J Cardiol [Internet]. 2016 Sep;219:150-5. Available from: https://linkinghub.elsevier.com/retrieve/pii/S016752731631049X 
18. Ouwerkerk W, Voors AA, Zwinderman AH. Factors Influencing the Predictive Power of Models for Predicting Mortality and/or Heart Failure Hospitalization in Patients With Heart Failure. JACC Hear Fail [Internet]. 2014 Oct;2(5):429-36. Available from: https://linkinghub.elsevier.com/retrieve/pii/S2213177914002558

19. Kang S-M, Cho M-C. Prognostic Factors in Hospitalization for Heart Failure in Asia. Heart Fail Clin [Internet]. 2015 Oct;11(4):543-50. Available from: https://linkinghub.elsevier.com/retrieve/pii/S1551713615000598

20. Testa G, Della-Morte D, Cacciatore F, Gargiulo G, D’Ambrosio D, Galizia G, et al. Precipitating Factors in Younger and Older Adults with Decompensated Chronic Heart Failure: Are They Different? J Am Geriatr Soc [Internet]. 2013 Oct;61(10):1827-8. Available from: https://onlinelibrary.wiley.com/doi/10.1111/igs.12475

21. Solomon SD, Rizkala AR, Lefkowitz MP, Shi VC, Gong J, Anavekar N, et al. Baseline Characteristics of Patients With Heart Failure and Preserved Ejection Fraction in the PARAGON-HF Trial. Circ Hear Fail [Internet]. 2018 Jul;11(7):e004962. Available from: https://www.ahajournals.org/doi/10.1161/CIRCHEARTFAILURE.118.004962

22. Tuppin $P$, Cuerq A, de Peretti C, Fagot-Campagna A, Danchin N, Juillière $Y$, et al. Two-year outcome of patients after a first hospitalization for heart failure: A national observational study. Arch Cardiovasc Dis [Internet]. 2014 Mar;107(3):158-68. Available from: https://linkinghub.elsevier.com/retrieve/pii/S1875213614000424

23. O'Connor CM, Abraham WT, Albert NM, Clare R, Gattis Stough W, Gheorghiade M, et al. Predictors of mortality after discharge in patients hospitalized with heart failure: An analysis from the Organized Program to Initiate Lifesaving Treatment in Hospitalized Patients with Heart Failure (OPTIMIZE-HF). Am Heart J [Internet]. 2008 Oct;156(4):662-73. Available from: https://linkinghub.elsevier.com/retrieve/pii/S0002870308003232

24. Cichocka-Radwan A, Lelonek M. Annual prognostic factors in chronic heart failure in patients over 80 years old. Kardiol Pol [Internet]. 2017 Feb 15;75(2):164-73. Available from: https://doi.org/10.5603/KP.a2016.0132

25. de Boer RA, Nayor M, DeFilippi CR, Enserro D, Bhambhani V, Kizer JR, et al. Association of Cardiovascular Biomarkers With Incident Heart Failure With Preserved and Reduced Ejection Fraction. JAMA Cardiol [Internet]. 2018 Mar 1;3(3):215-44. Available from: http://cardiology.jamanetwork.com/article.aspx?doi=10.1001/jamacardio.2017.4987

26. Li L, Mo Q, Mo T, Liu Y, Tian JL, Wan Z. Multicenter retrospectie analysis on clinical characteristics and pharmaceutical therapy of elderly Patients with chronic heart failure [in Chinese]. Zhonghua Yi Xue Za Zhi [Internet]. 2018 Mar 6;98(9):673-7. Available from: http://www.ncbi.nlm.nih.gov/pubmed/29534402

27. Pyka $Ł$, Hawranek M, Tajstra M, Gorol J, Lekston A, Gąsior M. Complete percutaneous revascularisation feasibility in ischaemic heart failure is related to improved outcomes: insights from the COMMIT-HF registry. Kardiol Pol [Internet]. 2017 May 17;75(5):453-61. Available from: https://journals.viamedica.pl/kardiologia polska/article/view/78459

28. Díez-Villanueva P, Alfonso F. Heart failure in the elderly. J Geriatr Cardiol [Internet]. 2016 Feb;13(2):115-7. Available from: http://www.ncbi.nlm.nih.gov/pubmed/27168735

29. Lip GYH, Laroche C, loachim PM, Rasmussen LH, Vitali-Serdoz L, Petrescu L, et al. Prognosis and treatment of atrial fibrillation patients by European cardiologists: One Year Follow-up of the EURObservational Research Programme-Atrial Fibrillation General Registry Pilot Phase (EORP-AF Pilot registry). Eur Heart J [Internet]. 2014 Dec 14;35(47):3365-76. Available from: https://academic.oup.com/eurheartj/article-lookup/doi/10.1093/eurhearti/ehu374

30. Staerk L, Wang B, Preis SR, Larson MG, Lubitz SA, Ellinor PT, et al. Lifetime risk of atrial fibrillation according to optimal, borderline, or elevated levels of risk factors: cohort study based on longitudinal data from the Framingham Heart Study. BMJ [Internet]. 2018 Apr 26;361:k1453. Available from: https://www.bmj.com/lookup/doi/10.1136/bmj.k1453

31. Santhanakrishnan R, Wang N, Larson MG, Magnani JW, McManus DD, Lubitz SA, et al. Atrial Fibrillation Begets Heart Failure and Vice Versa. Circulation [Internet]. 2016 Feb 2;133(5):484-92. Available from: https://www.ahajournals.org/ doi/10.1161/CIRCULATIONAHA.115.018614

32. Fumagalli S, Pelagalli G, Migliorini M, Boni S, Nigro F, Marozzi I, et al. The complex interaction between atrial fibrillation and heart failure in elderly patients. Monaldi Arch Chest Dis [Internet]. 2019 Jun 4;89(2). Available from: https://www. monaldi-archives.org/index.php/macd/article/view/1050

33. Sheikh Rezaei S, Weisshaar S, Litschauer B, Gouya G, Ohrenberger G, Wolzt M. ADMA and NT pro-BNP are associated with overall mortality in elderly. Eur J Clin Invest [Internet]. 2019 Jan;49(1):e13041. Available from: https://onlinelibrary. wiley.com/doi/10.1111/eci.13041

34. Vergaro G, Januzzi JL, Cohen Solal A, Aimo A, Arzilli C, Zyw L, et al. NT-proBNP prognostic value is maintained in elderly and very elderly patients with chronic systolic heart failure. Int J Cardiol [Internet]. 2018 Nov;271:324-30. Available from: https://linkinghub.elsevier.com/retrieve/pii/S0167527318307678

35. Upadhya B, Kitzman DW. Heart Failure with Preserved Ejection Fraction in Older Adults. Heart Fail Clin [Internet]. 2017 Jul;13(3):485-502. Available from: https://linkinghub.elsevier.com/retrieve/pii/S1551713617300181 
36. Goyal P, Kneifati-Hayek J, Archambault A, Mehta K, Levitan EB, Chen L, et al. Prescribing Patterns of Heart Failure-Exacerbating Medications Following a Heart Failure Hospitalization. JACC Hear Fail [Internet]. 2020 Jan;8(1):25-34. Available from: https://linkinghub.elsevier.com/retrieve/pii/S2213177919307243

37. Sung S-H, Wang T-J, Cheng H-M, Yu W-C, Guo C-Y, Chiang C-E, et al. Clinical Characteristics and Outcomes in the Very Elderly Patients Hospitalized for Acute Heart Failure: Importance of Pharmacologic Guideline Adherence. Sci Rep [Internet]. 2018 Dec 24;8(1):14270. Available from: http://www.nature.com/articles/s41598-018-32684-9

38. Knuuti J, Wijns W, Saraste A, Capodanno D, Barbato E, Funck-Brentano C, et al. 2019 ESC Guidelines for the diagnosis and management of chronic coronary syndromes. Eur Heart J [Internet]. 2020 Jan 14;41(3):407-77. Available from: https:// academic.oup.com/eurheartj/article/41/3/407/5556137

39. Bayoumi E, Lam PH, Dooley DJ, Singh S, Faselis C, Morgan CJ, et al. Spironolactone and Outcomes in Older Patients with Heart Failure and Reduced Ejection Fraction. Am J Med [Internet]. 2019 Jan;132(1):71-80.e1. Available from: https:// linkinghub.elsevier.com/retrieve/pii/S0002934318308787

40. Lee JE, Park E-C, Jang S-Y, Lee SA, Choy YS, Kim TH. Effects of Physician Volume on Readmission and Mortality in ElderIy Patients with Heart Failure: Nationwide Cohort Study. Yonsei Med J [Internet]. 2018;59(2):243-51. Available from: https://eymj.org/DOlx.php?id=10.3349/ymj.2018.59.2.243 